\title{
Classification of end-of-life decisions by Dutch physicians: findings from a cross-sectional survey
}

\author{
Anouk Overbeek ${ }^{1}$, Veerle E. van de Wetering ${ }^{2}$, Johannes J. M. van Delden ${ }^{3}$, Paul A. M. Mevis ${ }^{1}$, \\ Bregje D. Onwuteaka-Philipsen ${ }^{4}$, Liselotte Postma ${ }^{1}$, Judith A. C. Rietjens ${ }^{2}$, Agnes van der Heide ${ }^{2}$
}

${ }^{1}$ Department of Criminal Law, Erasmus University Rotterdam, Rotterdam, The Netherlands; ${ }^{2}$ Department of Public Health, Erasmus Medical Center Rotterdam, Rotterdam, The Netherlands; ${ }^{3}$ Department of Medical Humanities, University Medical Center Utrecht, Utrecht, The Netherlands; ${ }^{4}$ Department of Public and Occupational Health, Amsterdam Public Health Research Institute, Amsterdam University Medical Center, location VUmc, Amsterdam, The Netherlands

Contributions: (I) Conception and design: JJM van Delden, BD Onwuteaka-Philipsen, A van der Heide; (II) Administrative support: All authors; (III) Provision of study materials or patients: JJM van Delden, BD Onwuteaka-Philipsen, A van der Heide; (IV) Collection and assembly of data: JJM van Delden, BD Onwuteaka-Philipsen, A van der Heide; (V) Data analysis and interpretation: All authors; (VI) Manuscript writing: All authors; (VII) Final approval of manuscript: All authors.

Correspondence to: Anouk Overbeek. Department of Criminal Law, Erasmus University Rotterdam. P.O. Box 1738, 3000 DR Rotterdam, The Netherlands. Email: overbeek@law.eur.nl.

Background At the end of patients' lives, physicians sometimes provide medication with the explicit intention to hasten death. Physicians' assessment of such acts varies. We studied which characteristics are associated with physicians' classification of these acts.

Methods: This study concerns a secondary analysis of a nationwide study on the practice of medical decision-making at the end of life. In 2015, attending physicians of a sample of deceased people $(\mathrm{n}=9,351)$ received a questionnaire about end-of-life care and decision-making. The response rate was $78 \%$. We studied 851 cases in which physicians reported that the patient had died as a result of medication they had provided with the explicit intention to hasten death. Chi-square tests and logistic regression analyses were performed.

Results: If medication had been provided with the explicit intention to hasten death at the explicit request of the patient, physicians considered "euthanasia", "assisted suicide" or "ending of life" the most appropriate term for their course of action in $82 \%$ of all cases, while $17 \%$ of physicians chose the term "palliative or terminal sedation". Physicians' classification of their act as "euthanasia", "assisted suicide" or "ending of life" was less likely when patients had a short (1-7 days) or very short (max. 24 hours) life expectancy. Furthermore, such classification was less likely when their act had involved the use of other medication than muscle relaxants. The limited number of cases in which patients had been provided with medication without an explicit patient request were never classified as "euthanasia", "assisted suicide" or "ending of life".

Conclusions: Physicians rarely classify the provision of medication with the explicit intention of hastening death as "euthanasia", "assisted suicide" or "ending of life" when patients are in the dying phase and when they provide other medication than muscle relaxants. In these cases, acts are mostly classified as "palliative or terminal sedation". This suggests that the legal distinction between euthanasia and palliative care may not always be clear in clinical practice.

Keywords: Assisted suicide; euthanasia; medical decision-making

Submitted Feb 20, 2020. Accepted for publication May 14, 2020.

doi: $10.21037 / \mathrm{apm}-20-453$

View this article at: http://dx.doi.org/10.21037/apm-20-453 


\section{Introduction}

The Dutch Termination of Life on Request and Assisted Suicide Act (1) came into force in 2002. Under this Act, euthanasia and assisted suicide remain illegal as described in the Dutch Criminal Code, articles 293 and 294, but the special justification of article 293 paragraph 2 together with the Act provide a specific ground for exclusion of criminal liability for physicians when they report their actions to the local coroner and comply with due care criteria. After the local coroner has received a notification of the termination of life on request from the physician, including a written report regarding compliance with the due care criteria, the coroner sends the report to one of five Regional Euthanasia Review Committees. Each committee consists of a lawyer, a physician and an ethicist. The committee reviews every reported case and judges whether the physician has acted in accordance with the due care criteria (see Table 1 for criteria).

The interpretation of the legal criteria of due medical care has become more clear through their use in practice, in guidelines and in case law. The Royal Dutch Medical Association and the Royal Dutch Society for the Advancement of Pharmacy have provided guidance on how to perform euthanasia or assistance in suicide with due medical care (2). When performing euthanasia, the guidelines prescribe the administration of a barbiturate to induce coma, followed by a muscle relaxant that causes the death of the patient (2). For assisted suicide, the guidelines prescribe a sufficiently high dose of an orally administered barbiturate (2). If the Review Committee judges that the physician did not comply with the due care criteria, the public prosecutor's office and the Health Inspectorate are notified. Both authorities independently determine whether further steps are necessary.

The practice of end-of-life decision-making in the Netherlands has been studied in a series of nationwide surveys, that started in 1990 and were repeated every five years since then (3-10). In these studies, an act is classified as "euthanasia" or "assisted suicide" when the physician prescribes, supplies or administers medication with the explicit intention of hastening a patient's end of life, upon this patient's explicit request (11). In 2015, euthanasia was performed in $4.5 \%$ of all deaths, whereas physicians had provided assistance in suicide in $0.1 \%(3,11)$. Administration of medication with the explicit intention of hastening death without an explicit patient request had occurred in $0.3 \%$ of all deaths $(3,11)$.
A hypothetical case study on classification of end-oflife practices concluded that similar practices are not uniformly assessed by physicians (12). It was found that such assessment was strongly associated with the medication provided: the use of muscle relaxants made physicians' classification of cases as "euthanasia" or "ending of life" much more likely than the use of morphine or sedatives (12). Physicians were also found to be more inclined to classify acts as "euthanasia" or "ending of life" when the patient was expected to die within several months as compared to a few days (12).

The legal regulation and societal control of physicianassistance in dying requires a clear delineation of which acts should be considered to represent 'normal' medical practice and which acts go beyond that and should be reported to enable judicial review. We studied cases as reported in the 2015 nationwide survey with the aim of (I) getting insight in how Dutch physicians classify acts where they provided medication with the explicit intention to hasten death, with or without an explicit patient request, and (II) gaining more insight into factors associated with physicians' assessment of such acts. We present the following article in accordance with the SURGE reporting checklist (available at http:// dx.doi.org/10.21037/apm-20-453).

\section{Methods}

This study concerns a secondary analysis of data from a nationwide study on the practice of medical decisionmaking at the end of life (11). The nationwide study is based on a stratified sample from the death registry of Statistics Netherlands, to which all deaths are reported. All deaths that had occurred between August and November 2015 were assigned to one of ten strata on the basis of cause of death as indicated on the death certificate and the related likelihood that an end-of-life decision had preceded death. Strata with a higher likelihood of an end-of-life decision had a higher sampling probability. All attending physicians of sampled cases $(n=9,351)$ received a questionnaire about end-of-life care and decision-making that had preceded the death of the patient concerned. The response rate was $78 \%$. All data were absolutely anonymized and in addition the Ministry of Justice guaranteed that physicians would not be prosecuted on the basis of information given in the study. According to Dutch policy, the study did not require review by an ethics committee.

For this study we only included cases where the physician 
Table 1 Due care criteria

The due care criteria are stated in Article 2, paragraph 1 of the Dutch Termination of Life on Request and Assisted Suicide Act and imply that the physician must:

a. Be satisfied that the patient's request is voluntary and well-considered

b. Be satisfied that the patient's suffering is unbearable, with no prospect of improvement

c. Have informed the patient about his/her situation and prognosis

d. Have come to the conclusion, together with the patient, that there is no reasonable alternative in the patient's situation

e. Have consulted at least one other, independent physician, who must see the patient and give a written opinion on whether the due care criteria set out above have been fulfilled

f. Have exercised due medical care and attention in terminating the patient's life or assisting in the patient's suicide

responded "yes" to the following question: "Was death the result of medication that was prescribed, supplied or administered by you or another physician with the explicit intention of hastening the end of life (or of enabling the patient to end his or her own life)?" Other questions concerned the patient's request ("Was the act performed upon an explicit request of the patient?") and the physicians' classification of the act ("What do you think would be the best term for your act?").

All cases were weighted to adjust for the stratified sampling procedure and for differences in response rates in relation to demographics. As a result of the weighting procedure the percentages presented cannot be derived from the absolute unweighted numbers presented.

To determine which factors are associated with physicians' classification of acts we conducted chi-square tests and logistic regression analyses with the dependent variable being classification of the act as either active termination of life, which category included "euthanasia", "assisted suicide" or "ending of life", or otherwise. Potentially associated factors included patient characteristics (gender, age, major diagnosis, life expectancy), the setting (physicians' specialty, place of death) and type of medication provided. In addition, we analyzed possible consequences of physicians' classification regarding (I) asking the advice of an independent physician as required by law for euthanasia and physician-assisted suicide and (II) reporting of the act to a Regional Euthanasia Review Committee, using Chisquare tests.

\section{Results}

The number of studied cases was 851 in total, of which 834 included an explicit patient request for hastening of death and 17 did not. If medication had been provided with the explicit intention to hasten death at the explicit request of the patient, $82 \%$ of physicians considered "euthanasia", "assisted suicide" or "ending of life" (= active termination of life) the most appropriate term for their course of action; $17 \%$ chose the term "palliative or terminal sedation" and $2 \%$ "alleviation of symptoms" (Table 2). In cases where the act did not follow an explicit patient request, none of the respondents classified their course of action as active termination of life, while $93 \%$ opted for "palliative or terminal sedation", $3 \%$ for "alleviation of symptoms", and $4 \%$ for another term.

\section{Patient characteristics}

In cases where medication had been provided with the explicit intention to hasten death at the explicit request of the patient, classification of the act as active termination of life was less likely for patients aged 80 or over [67\%; odds ratio (OR): $0.11,95 \% \mathrm{CI}: 0.04-0.31]$ and patients aged 65-79 (87\%; OR: 0.36, 95\% CI: 0.12-1.07), as compared with patients up to 65 years (95\%; Table 3). Furthermore, classification was less likely for patients with cardiovascular diseases, lung diseases or diseases of the nervous system (69\%; OR: 0.34, 95\% CI: 0.18-0.64) and patients with other major diagnoses (72\%; OR: 0.39, 95\% CI: 0.19-0.83), as compared with cancer patients (87\%). Classification was also less likely if patients had a life expectancy of 24 hours or less (27\%; OR: $0.02,95 \%$ CI: $0.006-0.04)$ or one to seven days (71\%; OR: $0.11,95 \%$ CI: $0.05-0.24)$ as compared with patients who had a life expectancy of more than one week (96\%). 
Table 2 Most appropriate term according to Dutch physicians for acts where medication had been provided with the explicit intention to hasten death

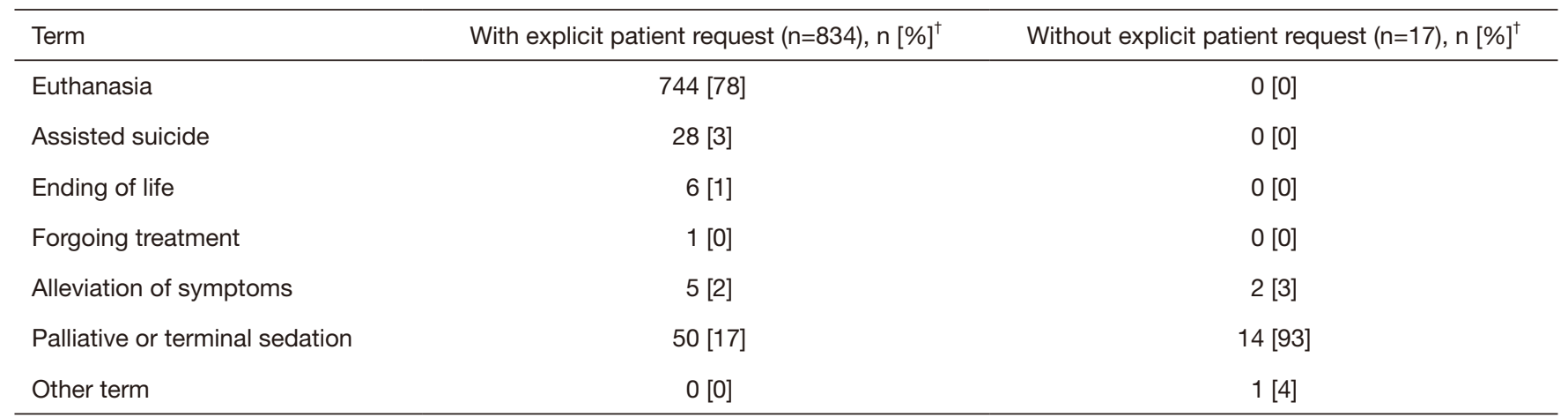

${ }^{\dagger}$, data are absolute numbers of patients (weighted \%). All percentages are weighted to make them representative of all cases where medication had been provided with the explicit intention to hasten death in the Netherlands in 2015. Therefore the percentages presented cannot be derived from the unweighted absolute numbers.

\section{Setting}

The likelihood of classification of the act as active termination of life was lower if the procedure had been performed by physicians with a specialty other than general practitioner (55\%; OR: 0.24, 95\% CI: 0.11-0.53). Moreover, this likelihood was lower when the patient had died outside the home setting (61\%; OR: $0.23,95 \%$ CI: $0.13-0.40)$. In other words, if the act occurred at home and was performed by a general practitioner, classification as active termination of life was more likely.

\section{Type of medication provided}

Type of medication turned out to be associated with classification of the act: if barbiturates (all combinations, excluding muscle relaxants; $72 \%$, OR: 0.01, 95\% CI: $0.001-$ 0.09 ) or other medication (3\%; OR: $0.00,95 \%$ CI: 0.00 0.002 ) had been provided, the likelihood of classification of the act as active termination of life was less than if muscle relaxants had been used (all combinations; 99\%).

Results of a multiple logistic regression analysis showed that both life expectancy $(\mathrm{P}=0.03)$ and type of medication $(\mathrm{P}=0.00)$ were significantly associated with classification of the act as active termination of life (Table 3). Other factors were not significantly associated with classification as active termination of life in this analysis.

\section{Consequences of the classification}

If physicians classified their course of action as active termination of life, $99 \%$ of them had asked advice of an independent physician and $99 \%$ had reported the case to a Regional Euthanasia Review Committee. If the course of action was not classified as active termination of life, $65 \%$ of physicians had asked advice and no case had been reported to a Regional Euthanasia Review Committee.

\section{Cases without an explicit patient request}

In Table 4 we present (unweighted) characteristics of 17 cases where medication had been provided with the explicit intention to hasten death without the explicit request of the patient. In 8 cases the physician had discussed the hastening of death with the patient. In other cases there had been no discussion of the act, which was mostly due to the fact that the patients concerned were not deemed competent or capable of making a request due to dementia $(n=3)$ or a coma $(n=3)$. The act had been performed by administration of a muscle relaxant in 2 cases, once in combination with a barbiturate and once in combination with morphine. In 13 other cases, the physician had administered morphine, eight times in combination with a benzodiazepine. In one case only a benzodiazepine had been administered and in one case it is unknown which medication had been provided. Physicians indicated in 7 cases that the estimated life expectancy had been less than 24 hours, in 5 cases it had been one to seven days, and in 4 cases more than one week. The estimated life expectancy of one patient is unknown.

\section{Discussion}

If physicians had provided medication with the explicit 
Table 3 Associations between patient characteristics, setting and medication provided, and physicians' classification of an act as "active termination of life" (either "euthanasia", "assisted suicide" or "ending of life"), n=834

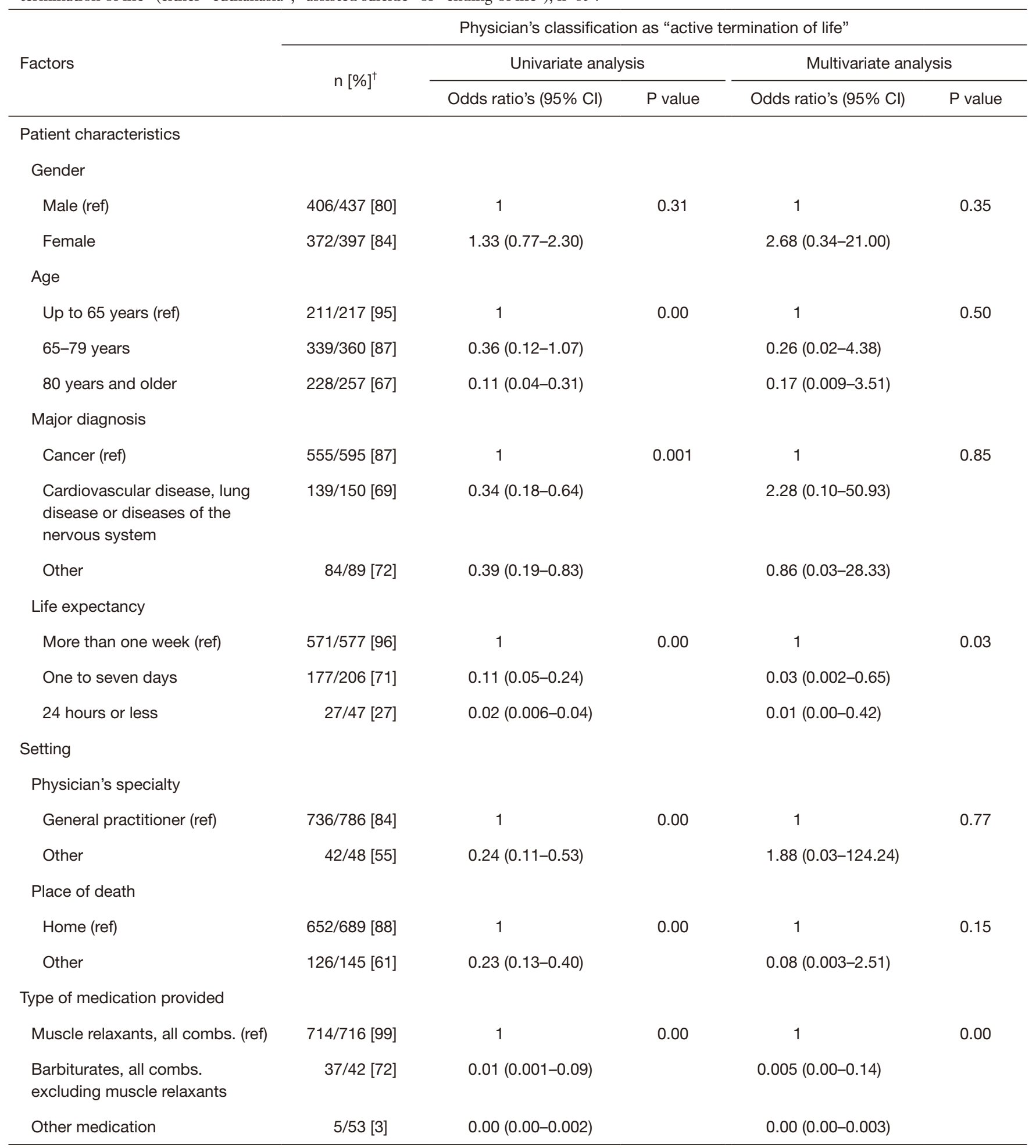

${ }^{\dagger}$, data are absolute numbers of patients (weighted \%). All percentages are weighted to make them representative of all cases where medication had been provided with the explicit intention to hasten death in the Netherlands in 2015. Therefore the percentages presented cannot be derived from the unweighted absolute numbers. 
Table 4 Characteristics of 17 cases where medication had been provided with the explicit intention to hasten death without the explicit request of the patient

\begin{tabular}{|c|c|c|c|c|c|c|c|c|c|c|c|c|c|c|c|c|c|}
\hline Characteristics & 1 & 2 & 3 & 4 & 5 & 6 & 7 & 8 & 9 & 10 & 11 & 12 & 13 & 14 & 15 & 16 & 17 \\
\hline $\begin{array}{l}\text { Classification of } \\
\text { act by physician }\end{array}$ & $\begin{array}{l}\text { Palliative } \\
\text { or terminal } \\
\text { sedation }\end{array}$ & $\begin{array}{l}\text { Palliative } \\
\text { or terminal } \\
\text { sedation }\end{array}$ & $\begin{array}{l}\text { Alleviation of } \\
\text { symptoms }\end{array}$ & $\begin{array}{l}\text { Palliative } \\
\text { or terminal } \\
\text { sedation }\end{array}$ & $\begin{array}{l}\text { Palliative } \\
\text { or terminal } \\
\text { sedation }\end{array}$ & $\begin{array}{l}\text { Palliative } \\
\text { or terminal } \\
\text { sedation }\end{array}$ & $\begin{array}{l}\text { Palliative } \\
\text { or terminal } \\
\text { sedation }\end{array}$ & $\begin{array}{l}\text { Best supportive } \\
\text { care }\end{array}$ & $\begin{array}{l}\text { Palliative } \\
\text { or terminal } \\
\text { sedation }\end{array}$ & $\begin{array}{l}\text { Palliative } \\
\text { or terminal } \\
\text { sedation }\end{array}$ & $\begin{array}{l}\text { Palliative } \\
\text { or terminal } \\
\text { sedation }\end{array}$ & $\begin{array}{l}\text { Palliative } \\
\text { or terminal } \\
\text { sedation }\end{array}$ & $\begin{array}{l}\text { Palliative } \\
\text { or terminal } \\
\text { sedation }\end{array}$ & $\begin{array}{l}\text { Palliative } \\
\text { or terminal } \\
\text { sedation }\end{array}$ & $\begin{array}{c}\text { Palliative or } \\
\text { terminal sedation }\end{array}$ & $\begin{array}{c}\text { Palliative or } \\
\text { terminal sedation }\end{array}$ & $\begin{array}{l}\text { Alleviation of } \\
\text { symptoms }\end{array}$ \\
\hline $\begin{array}{l}\text { Physicians' } \\
\text { speciality }\end{array}$ & $\begin{array}{l}\text { Elderly care } \\
\text { physician }\end{array}$ & $\begin{array}{l}\text { Elderly care } \\
\text { physician }\end{array}$ & $\begin{array}{c}\text { General } \\
\text { practitioner }\end{array}$ & $\begin{array}{c}\text { General } \\
\text { practitioner }\end{array}$ & $\begin{array}{c}\text { General } \\
\text { practitioner }\end{array}$ & $\begin{array}{l}\text { Elderly care } \\
\text { physician }\end{array}$ & $\begin{array}{c}\text { General } \\
\text { practitioner }\end{array}$ & Pulmonologist & $\begin{array}{c}\text { General } \\
\text { practitioner }\end{array}$ & $\begin{array}{c}\text { General } \\
\text { practitioner }\end{array}$ & Pulmonologist & $\begin{array}{c}\text { General } \\
\text { Practitioner }\end{array}$ & Surgeon & Pulmonologist & $\begin{array}{c}\text { Intensivist/ } \\
\text { anaesthesiologist }\end{array}$ & $\begin{array}{c}\text { Intensivist/ } \\
\text { anaesthesiologist }\end{array}$ & $\begin{array}{l}\text { Elderly care } \\
\text { physician }\end{array}$ \\
\hline Gender patient & Female & Male & Male & Male & Female & Male & Male & Male & Female & Female & Male & Female & Female & Male & Male & Female & Female \\
\hline Age patient & $65-79$ & $80+$ & $80+$ & $17-64$ & $80+$ & $65-79$ & $80+$ & $80+$ & $80+$ & $65-79$ & $65-79$ & $17-64$ & $17-64$ & $65-79$ & $17-64$ & $65-79$ & $17-64$ \\
\hline Main diagnosis & $\begin{array}{c}\text { Disease of the } \\
\text { nervous system }\end{array}$ & Other & Cancer & Cancer & Other & $\begin{array}{l}\text { Disease of the } \\
\text { nervous system }\end{array}$ & Cancer & Cancer & Other & Cancer & Cancer & Cancer & Cancer & Cancer & $\begin{array}{l}\text { Cardiovascular } \\
\text { disease }\end{array}$ & $\begin{array}{l}\text { Cardiovascular } \\
\text { disease }\end{array}$ & Other \\
\hline Life expectancy & Max 24 hours & Max 24 hours & $>1$ week & $1-7$ days & Max 24 hours & Max 24 hours & $1-7$ days & Max 24 hours & $1-7$ days & $1-7$ days & Max 24 hours & ? & $>1$ week & $1-7$ days & Max 24 hours & $>1$ week & $>1$ week \\
\hline Place of death & Nursing home & Nursing home & Home & Hospice & Care home & Nursing home & Home & Hospital & Hospital & Other & Hospital & Home & Hospital & Hospital & Other place & Hospital & Nursing home \\
\hline $\begin{array}{l}\text { Type of } \\
\text { medication }\end{array}$ & $\begin{array}{c}\text { Morphine }+ \\
\text { benzodiazepine }\end{array}$ & $\begin{array}{c}\text { Morphine }+ \\
\text { benzodiazepine }\end{array}$ & $\begin{array}{l}\text { Muscle relaxant } \\
\text { + barbiturate }\end{array}$ & Benzodiazepine & Morphine & Morphine & $\begin{array}{c}\text { Morphine }+ \\
\text { benzodiazepine }\end{array}$ & Morphine & $\begin{array}{c}\text { Other } \\
\text { medication }\end{array}$ & $\begin{array}{c}\text { Morphine + } \\
\text { benzodiazepine }\end{array}$ & Morphine & $\begin{array}{c}\text { Muscle relaxant } \\
+ \text { Morphine }\end{array}$ & $\begin{array}{c}\text { Morphine + } \\
\text { benzodiazepine }\end{array}$ & $\begin{array}{c}\text { Morphine + } \\
\text { benzodiazepine }\end{array}$ & $\begin{array}{c}\text { Morphine + } \\
\text { benzodiazepine }\end{array}$ & Morphine & $\begin{array}{c}\text { Morphine + } \\
\text { benzodiazepine }\end{array}$ \\
\hline $\begin{array}{l}\text { Consultation of } \\
\text { patient }\end{array}$ & $\begin{array}{l}\text { Not at the time } \\
\text { of the act, but } \\
\text { patient had } \\
\text { expressed wish } \\
\text { to hasten death } \\
\text { at an earlier } \\
\text { stage }\end{array}$ & No & Yes & Yes & No & $\begin{array}{l}\text { Not at the time } \\
\text { of the act, but } \\
\text { patient had } \\
\text { expressed wish } \\
\text { to hasten death } \\
\text { at an earlier } \\
\text { stage }\end{array}$ & Yes & Yes & Yes & No & Yes & $\begin{array}{l}\text { Not at the time } \\
\text { of the act, but } \\
\text { patient had } \\
\text { expressed wish } \\
\text { to hasten death } \\
\text { at an earlier } \\
\text { stage }\end{array}$ & No & Yes & No & No & Yes \\
\hline $\begin{array}{l}\text { Reason no } \\
\text { consult }\end{array}$ & Dementia & Dementia & - & - & ? & Dementia & - & - & 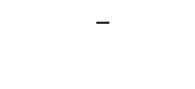 & Diverse & - & ? & Comatose & - & Comatose & Comatose & - \\
\hline $\begin{array}{l}\text { Patient } \\
\text { competent? }\end{array}$ & No & No & Yes & Yes & No & Yes & Yes & Yes & Yes & No & Yes & ? & No & No & No & No & Yes \\
\hline \multicolumn{18}{|l|}{$\begin{array}{l}\text { Consultation of } \\
\text { others }\end{array}$} \\
\hline Physicians & Yes & No & No & Yes & No & ? & No & No & Yes & No & Yes & Yes & Yes & No & Yes & Yes & Yes \\
\hline Nurses & No & No & No & No & Yes & ? & No & Yes & No & Yes & Yes & No & No & No & Yes & No & Yes \\
\hline $\begin{array}{l}\text { Partner/family } \\
\text { members }\end{array}$ & Yes & Yes & No & Yes & Yes & ? & Yes & Yes & Yes & No & Yes & No & No & No & Yes & No & Yes \\
\hline $\begin{array}{l}\text { Reason for } \\
\text { providing } \\
\text { medication with } \\
\text { explicit intention } \\
\text { to hasten death }\end{array}$ & Pain, symptoms & $\begin{array}{l}\text { Pain, symptoms, } \\
\text { dignity, wish } \\
\text { family, expected } \\
\text { suffering, } \\
\text { hopelessness, } \\
\text { further treatment } \\
\text { too stressful }\end{array}$ & t & $\begin{array}{l}\text { Expected } \\
\text { suffering, } \\
\text { hopelessness }\end{array}$ & $\begin{array}{c}\text { Dignity, } \\
\text { expected } \\
\text { suffering, } \\
\text { hopelessness }\end{array}$ & $\begin{array}{l}\text { Pain, dignity, } \\
\text { expected } \\
\text { suffering, } \\
\text { hopelessness, } \\
\text { further treatment } \\
\text { too stressful }\end{array}$ & $\begin{array}{l}\text { Pain, symptoms, } \\
\text { wish patient, } \\
\text { wish hamily, } \\
\text { hopelessness }\end{array}$ & $\begin{array}{l}\text { Pain, symptoms, } \\
\text { hopelessness }\end{array}$ & $\begin{array}{l}\text { Symptoms, } \\
\text { expected } \\
\text { suffering, } \\
\text { hopelessness }\end{array}$ & $\begin{array}{l}\text { Symptoms, } \\
\text { expected } \\
\text { suffering, } \\
\text { hopelessness }\end{array}$ & Pain & $\begin{array}{l}\text { Pain, dignity, } \\
\text { wish patient, } \\
\text { expected } \\
\text { suffering, } \\
\text { hopelessness }\end{array}$ & $\begin{array}{l}\text { Symptoms, } \\
\text { expected } \\
\text { suffering, } \\
\text { hopelessness }\end{array}$ & Symptoms & Hopelessness & $\begin{array}{l}\text { Dignity, expected } \\
\text { suffering, } \\
\text { hopelessness }\end{array}$ & $\begin{array}{c}\text { Pain, } \\
\text { symptoms, } \\
\text { expected } \\
\text { suffering, } \\
\text { hopelessness }\end{array}$ \\
\hline
\end{tabular}


intention to hasten death at the explicit request of the patient, $82 \%$ of them considered either "euthanasia", "assisted suicide" or "ending of life" the most appropriate term for their course of action. In the remaining cases, physicians chose "palliative or terminal sedation" (17\%) or "alleviation of symptoms" (2\%) as the most appropriate term. Both patients' life expectancy and the type of medication provided were significantly associated with physicians' classification of their act as active termination of life. If other medication than muscle relaxants had been used, the likelihood of a classification as active termination of life was lower. Furthermore, physicians classified their course of action less often as active termination of life when patients had a very short life expectancy, i.e., only hours or a few days.

This study also provides insight in characteristics of cases where medication had been provided with the explicit intention to hasten death without the explicit request of the patient. Patients in these cases typically had a life expectancy of only hours up to a few days. Physicians had mostly administered morphine and benzodiazepines, except in two cases where muscle relaxants had been used. It seems that at least these two cases should have been classified as active termination of life and thus reported to enable judicial review. However, physicians seem to classify none of these acts as active termination of life, but rather as palliative or terminal sedation. As a consequence, all 17 cases were considered to have involved natural deaths which did not require judicial review.

Our findings suggest that physicians are less inclined to classify hastening of death as active termination of life when it concerns patients who are in the dying phase. The dying phase is defined as the phase that immediately precedes death, where the patient is expected to die within a few days (13). Possibly, physicians consider the prevention of futile suffering during a prolonged dying process to be part of regular care of dying patients. The Dutch Termination of Life on Request and Assisted Suicide Act does not address the dying phase, or patients' life expectancy in general, as being a relevant factor in the judgement of the physician's act. Other countries that have a euthanasia act do not differentiate between patients who are in the dying phase and those who are not. In some countries however, patients need to have a maximum life expectancy $(14,15)$.

The dying phase has played a prominent role in discussions about the regulation of euthanasia in the Netherlands, especially when it comes to active termination of life without an explicit patient's request. The Remmelink Committee, which was appointed by the Dutch government to investigate the practice and regulation of medical endof-life decisions, described in their report in 1991 that they were willing to accept the ending of a patient's life without their explicit request if this patient's vital functions begin to fail. If the patient's suffering is unbearable in such circumstances, termination of life should be regarded as "normal" medical practice according to the committee. However, this viewpoint was rejected by the Dutch government and has never been included in regulations or guidelines. The Dutch government felt that the viewpoint of the committee was not acceptable on the basis of case law (16-19). It has also been discussed whether being in the dying phase in itself is sufficient to justify the administration of muscle relaxants. Case law clarifies it is not: general practitioner Van Oijen was convicted for murder because he administered a muscle relaxant to a comatose patient who was in the dying phase in 1997. Although the very short life expectancy of the patient was mentioned in their verdict in this case by both the Court and the Supreme Court, it has not been a decisive criterion in their judgment (20).

In both the presence and absence of an explicit patient request, physicians rarely classified the provision of medication with the explicit intention of hastening death as active termination of life when patients had been in the dying phase and when they had provided other medication than muscle relaxants. Most physicians considered "palliative or terminal sedation" the most appropriate term in these cases. The terms that were preferred by physicians suggest that their focus was on alleviating the suffering of the patient, with hastening of death as a means to achieve that goal $(21,22)$.

\section{Strengths and limitations}

Strengths of this study include the high response rate and a substantial sample of deaths that is representative for all cases where medication had been provided with the explicit intention to hasten death in the Netherlands in 2015. A limitation is that all information is derived from physicians. This approach allowed us to get insight into physicians' experiences, such as their intentions when performing a medical procedure. It is unclear, however, to what extent they adequately assessed the life-shortening effect of the medication they had provided. Whether opioids or sedatives, e.g., result in hastening of death is often difficult to judge. 


\section{Conclusions}

Our findings indicate that the legal distinction between euthanasia and palliative sedation is not always clear for physicians. This uncertainty in classification is described in other studies as well and is sometimes referred to as the "grey area" (23-25). Law however assumes that there is clarity in the delineation between the two practices, in both theory of regulation and medical practice, with farreaching consequences. Recognition of the grey area and the related differences in interpretation of specific acts is important. Both physicians and lawyers need to elaborate on how the legal classification of medical procedures can be more aligned with physicians' perceptions of their acts. To limit the number of cases in the grey area as much as possible, the distinction between active termination of life and palliative sedation should be included in the curriculum of medical students and in advanced training of physicians in palliative and end-of-life care. However, whereas there is a moral duty to diminish the number of cases in the grey area, it may not always possible to completely delineate one practice from another. That is why it is of the essence that physicians continue to earn public trust by being transparent about their acts.

\section{Acknowledgments}

The authors thank Daan Nieboer for his statistical support. Funding: This study concerns a secondary analysis of data from a nationwide study on the practice of medical decision-making at the end of life, which was financed by the Netherlands Organization for Health Research and Development (ZonMw).

\section{Footnote}

Provenance and Peer Review: This article was commissioned by the Guest Editors (Nancy Preston, Sheri Mila Gerson) for the series "Hastened Death" published in Annals of Palliative Medicine. The article has undergone external peer review.

Reporting Checklist: The authors have completed the SURGE reporting checklist. Available at http://dx.doi. org/10.21037/apm-20-453

Conflicts of Interest: All authors have completed the ICMJE uniform disclosure form (available at http:// dx.doi.org/10.21037/apm-20-453). The series "Hastened Death" was commissioned by the editorial office without any funding or sponsorship. All authors report grants from Netherlands Organization for Health Research and Development (ZonMw), during the conduct of the study. ZonMw had no role in study design; collection, analysis, and interpretation of data; writing of the report and the decision to submit the report for publication. All authors have full access to all of the data in this study and take complete responsibility for the integrity of the data and the accuracy of the data analysis.

Ethical Statement: The authors are accountable for all aspects of the work in ensuring that questions related to the accuracy or integrity of any part of the work are appropriately investigated and resolved.

Open Access Statement: This is an Open Access article distributed in accordance with the Creative Commons Attribution-NonCommercial-NoDerivs 4.0 International License (CC BY-NC-ND 4.0), which permits the noncommercial replication and distribution of the article with the strict proviso that no changes or edits are made and the original work is properly cited (including links to both the formal publication through the relevant DOI and the license). See: https://creativecommons.org/licenses/by-nc-nd/4.0/.

\section{References}

1. Korthals A. Staatsblad van het Koningrijk der Nederlanden. Available online: https://zoek. officielebekendmakingen.nl/stb-2001-194.html (accessed 17 July, 2018).

2. Royal Dutch Medical Association \& Royal Dutch Society for the Advancement of Pharmacy: Guidelines for the practice of euthanasia and assisted suicide, August 2012. Available online: https://www.knmp.nl/downloads/ guidelines-for-the-practice-of-euthanasia.pdf (accessed 11 November, 2019).

3. van der Heide A, van Delden JJM, Onwuteaka-Philipsen BD. End-of-life decisions in the Netherlands over 25 years. N Engl J Med 2017;377:492-4.

4. Onwuteaka-Philipsen BD, Brinkman-Stoppelenburg A, Penning C, et al. Trends in end-of-life practices before and after the enactment of the euthanasia law in the Netherlands from 1990 to 2010: a repeated cross-sectional survey. Lancet 2012;380:908-15.

5. van der Heide A, Onwuteaka-Philipsen BD, Rurup ML, 
et al. End-of-life practices in the Netherlands under the Euthanasia Act. N Engl J Med 2007;356:1957-65.

6. Onwuteaka-Philipsen BD, van der Heide A, Koper D, et al. Euthanasia and other end-of-life decisions in the Netherlands in 1990, 1995, and 2001. Lancet 2003;362:395-9.

7. van der Wal G, van der Maas PJ, Bosma JM, et al. Evaluation of the notification procedure for physicianassisted death in the Netherlands. N Engl J Med 1996;335:1706-11.

8. van Der Maas PJ, van Delden JJ, Pijnenborg L, et al. Euthanasia and other medical decisions concerning the end of life. Lancet 1991;338:669-74.

9. van der Maas PJ, van Der Wal G, Haverkate I, et al. Euthanasia, physician-assisted suicide, and other medical practices involving the end of life in the Netherlands, 1990-1995. N Engl J Med 1996;335:1699-705.

10. Rietjens JA, Heijltjes MT, van Delden JJ, et al. The rising frequency of continuous deep sedation in the Netherlands, a Repeated Cross-Sectional Survey in 2005, 2010, and 2015. J Am Med Dir Assoc 2019;20:1367-72.

11. Onwuteaka-Philipsen B, Legemaate J, van der Heide A, et al. Derde evaluatie Wet toetsing levensbeëindiging op verzoek en hulp bij zelfdoding. The Hague; 2017.

12. Buiting HM, van der Heide A, Onwuteaka-Philipsen BD, et al. Physicians' labelling of end-of-life practices: a hypothetical case study. J Med Ethics 2010;36:24-9.

13. van Zuylen L, van Veluw H, van Esch J. Richtlijn zorg in de stervensfase. Available online: https://www. pallialine.nl/index.php?pagina=/richtlijn/item/pagina . php\&id=32584\&richtlijn_id=770 (accessed 8 August, 2018).

14. Government of Oregon: Death with Dignity Act Requirements. Available online: https://www.oregon. gov/oha/PH/PROVIDERPARTNERRESOURCES/ EVALUATIONRESEARCH/ DEATHWITHDIGNITYACT/Documents/

Cite this article as: Overbeek A, van de Wetering VE, van Delden JJM, Mevis PAM, Onwuteaka-Philipsen BD, Postma L, Rietjens JAC, van der Heide A. Classification of end-of-life decisions by Dutch physicians: findings from a cross-sectional survey. Ann Palliat Med 2021;10(3):3554-3562. doi: 10.21037/apm20-453 requirements.pdf (accessed 11 November, 2019).

15. Parliament of Victoria: Voluntary Assisted Dying Bill 2017. Available online: https://www.parliament.vic.gov. au/publications/research-papers/download/36-researchpapers/13834-voluntary-assisted-dying-bill-2017 (accessed 25 September, 2019).

16. Kamerstukken II 1991/92. 20383, 14:7.

17. Van Tol D. Grensgeschillen; een rechtssociologisch onderzoek naar het classificeren van euthanasie en ander medisch handelen rond het levenseinde. Groningen: University of Groningen; 2005.

18. Weyers H. Euthanasie: Het proces van Rechtsverandering. Groningen: University of Groningen; 2002.

19. van Delden JJ, Pijnenborg L, van der Maas PJ. The Remmelink study: two years later. Hastings Cent Rep 1993;23:24-7.

20. HR 9 november 2009. NJ 2005/217. m.nt. Buruma.

21. Pijnenborg L, van der Maas PJ, Looman C, et al. Lifeterminating acts without explicit request of patient. Lancet 1993;341:1196-9.

22. Chambaere K, Bernheim JL, Downar J, et al. Characteristics of Belgian "life-ending acts without explicit patient request": a large-scale death certificate survey revisited. CMAJ Open 2014;2:E262.

23. van de Wetering VE, van der Heide A, Mevis PA. De meldplicht van de arts. Een problematisch aspect in het strafrechtelijk controlemechanisme bij euthanasie en hulp bij zelfdoding. DD 2018/64. 2018:804-24.

24. Cohen-Almagor R, Ely EW. Euthanasia and palliative sedation in Belgium. BMJ Support Palliat Care 2018;8:307-13.

25. van de Wetering VE, Mevis PA, van der Heide A. De grens tussen strafbare euthanasie en medische palliatieve sedatie; over de 'Typizität' van levensbeëindigend handelen. RM Themis 2019:233-46. 